\title{
Seismic microzoning maps for restoration of monuments in Seville: Nuestra Señora de los Reyes Convent
}

\author{
A. Jaramillo Morilla \& E. J. Mascort Albea \\ Department of Building Structures and Geotechnical Engineering, University of Seville, Seville, Spain \\ J. Ruiz Jaramillo \\ Department of Architectural Constructions, University of Málaga, Málaga, Spain
}

doi: 10 14575/gl/rehab2014/094

\begin{abstract}
Historic buildings are the most difficult structures to repair. Materials used in architectural Heritage are not usually adequate to withstand earthquakes. Furthermore, in Spain, seismic standard does not specify the treatment to be performed in these buildings. Nuestra Señora de los Reyes Convent, placed in Seville (Spain), had been acquired as public building for Autonomic Government from the beginning of XXI century. Its new use has required prior inspection and monitoring of the building. Collaborating with official refurbishing works, a series of Seville city ground maps have been performed with a database which contains almost 400 prospectings. In addition, university researchers have elaborated new geotechnical documents. As a result of these tests and inspections, researchers have obtained several suggestions for convent restoration works: reinforcing ground properties with injected concrete; using shallow foundations which must have similar properties as historical foundations; and finally, controlling for characteristics of made-ground used for land movements.
\end{abstract}

\section{INTRODUCTION}

When thinking about rehabilitation of monuments, we need to consider two main relevant issues: firstly, tests in order to study materials and characteristics must be as mild as possible. On the other hand, these buildings are a significant age and built to last hundreds of years, instead of 50-100 years lifetime of most of new constructions.

Works at Virgen de los Reyes Convent are part of a monumental restoration plan developed since 1975 by Autonomic Government, Junta de Andalucía. The knowledge of the terrain is essential to the regeneration of andalusian monuments. Thanks to collaborative work carried out by Geotechnical Engineering researchers from University of Seville, a deeper understanding of the city terrain nature has been possible.

Obtention of C terrain coefficient (NCSE-2002) which shows seismic acceleration amplification from a borehole series, has been a great innovation in the latest geotechnical maps.

\section{NON DESTRUCTIVE TESTS}

Nowadays, when a building presents symptons such as excessive deformations, fissures, cracks and moisture, it is usual to plan a testing and trial process which on many occasions damages part of the building. If it is a heritage building, coating and part of structural elements may be seriously damaged.

Regarding to building diagnostics, we are at 1800 s or beginning or 1900 s level. 
We are more than a century delayed in respect of building research techniques and diagnostics.

Destructives methods and tests are usually used to diagnose a building, being particularly harmful in heritage buildings, where structure, foundation and constructive elements are important issues, as well as coatings, which may be even more relevant.

Former Nuestra Señora de los Reyes convent was acquired by Autonomic Government in the 1980 s as Directorate General of Architecture headquarters.

First phase of refurbishment included the entrance courtyard, the church and some rooms. The building is currently being used as conference room, exhibition gallery, meeting and classrooms, most of them linked to architecture.

Some intrusive tests have been carried out, such as soil test pits, mortar resistance tests, boreholes and Standard Penetration Tests (SPT). In addition, non destructive testing including georadar profiles and natural vibration measurement have been performed.

\subsection{Standard Penetration Tests}

Accurate terrain characterisation is obtained through these tests, in combination with boreholes and soil test pits.

\subsection{Geo-radar}

The profiles performed from the convent, together with the boreholes and soil test pits, enable an accurate terrain characterisation. Geo-radar profiles confirm the existence of soft fill layers, according to SPT testing (Jaramillo, 2013).

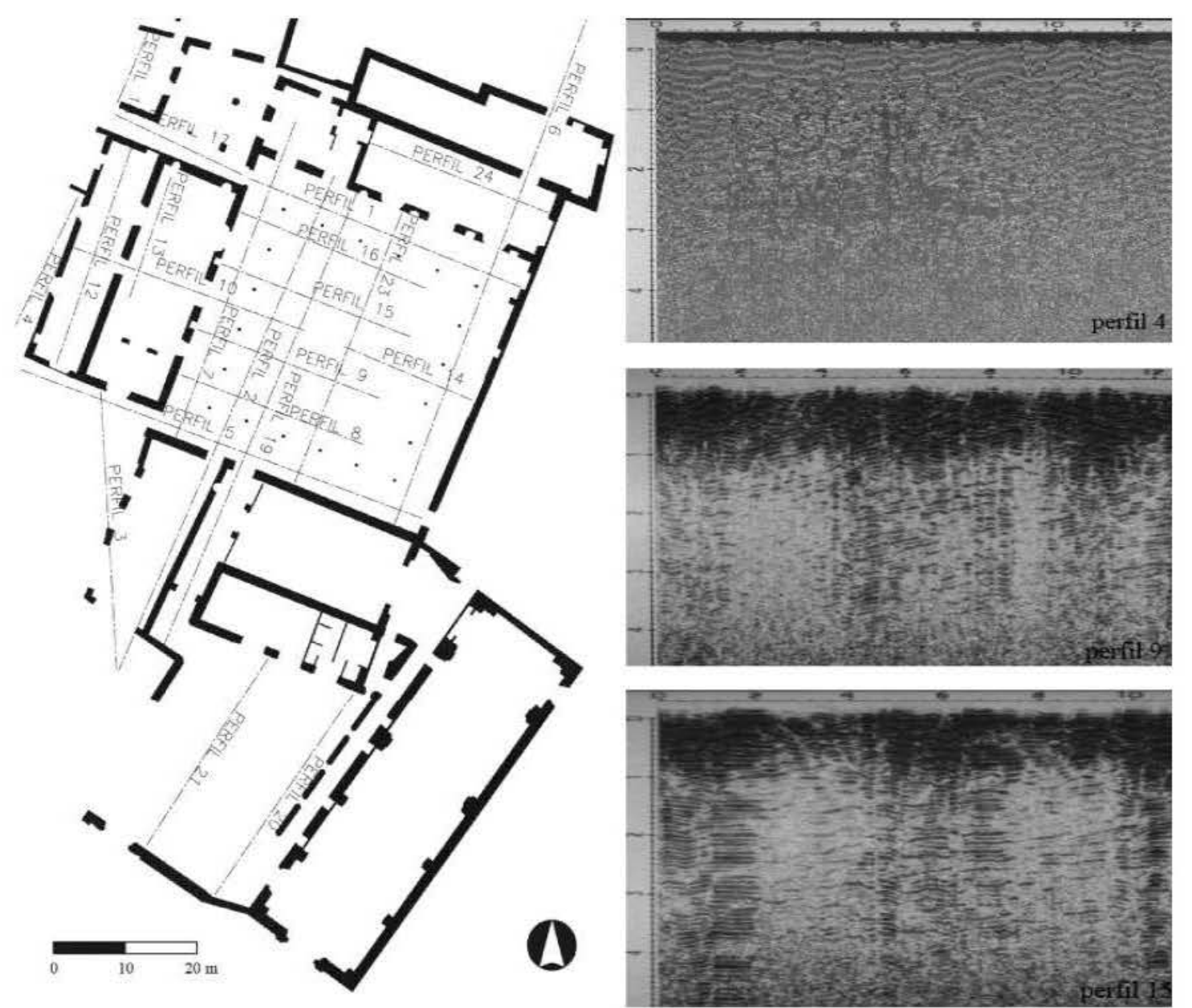

Figure 1. On the left, floor plan showing geo-radar tracing in the Convent. On the right, most relevant profiles showing soft fill-in layers. 


\subsection{Ultrasound measurements}

Ultrasounds are used in order to know material rigidity, measuring the propagation of a wave sent by an emitter or received by a translator.

The higher the speed the lower material modulus of elasticity and resistance. For example, tests on marble columns were performed showing speeds from 2100 to $4500 \mathrm{~km} / \mathrm{s}$.

\subsection{Natural vibration measurements}

This measures the vibration spectrum produced in the building due to environmental conditions in order to obtain a structural rigidity value. ISO $4866 / 1990$ is the reference regulation.

It is based on the material property submitted to a random wavefront, which filters frequences depending on its physical features and its boundary conditions. This frequence is related to its rigidity, linking destabilizing force (vibration dynamic effort) and displacement produced by this force (frequence/displacement spectrum), enabling to know some material parameters.

Although values obtained through this method are related to execution conditions and building geometry, since this is a non destructive test in situ, measure point choice must embrace all possible circumstances; in this case they were the midspan and three orthogonal axis $(X, Y$ and Z) for every floor slab tested. Following results were obtained from Sig v1.9 program (Povedano, 2013).
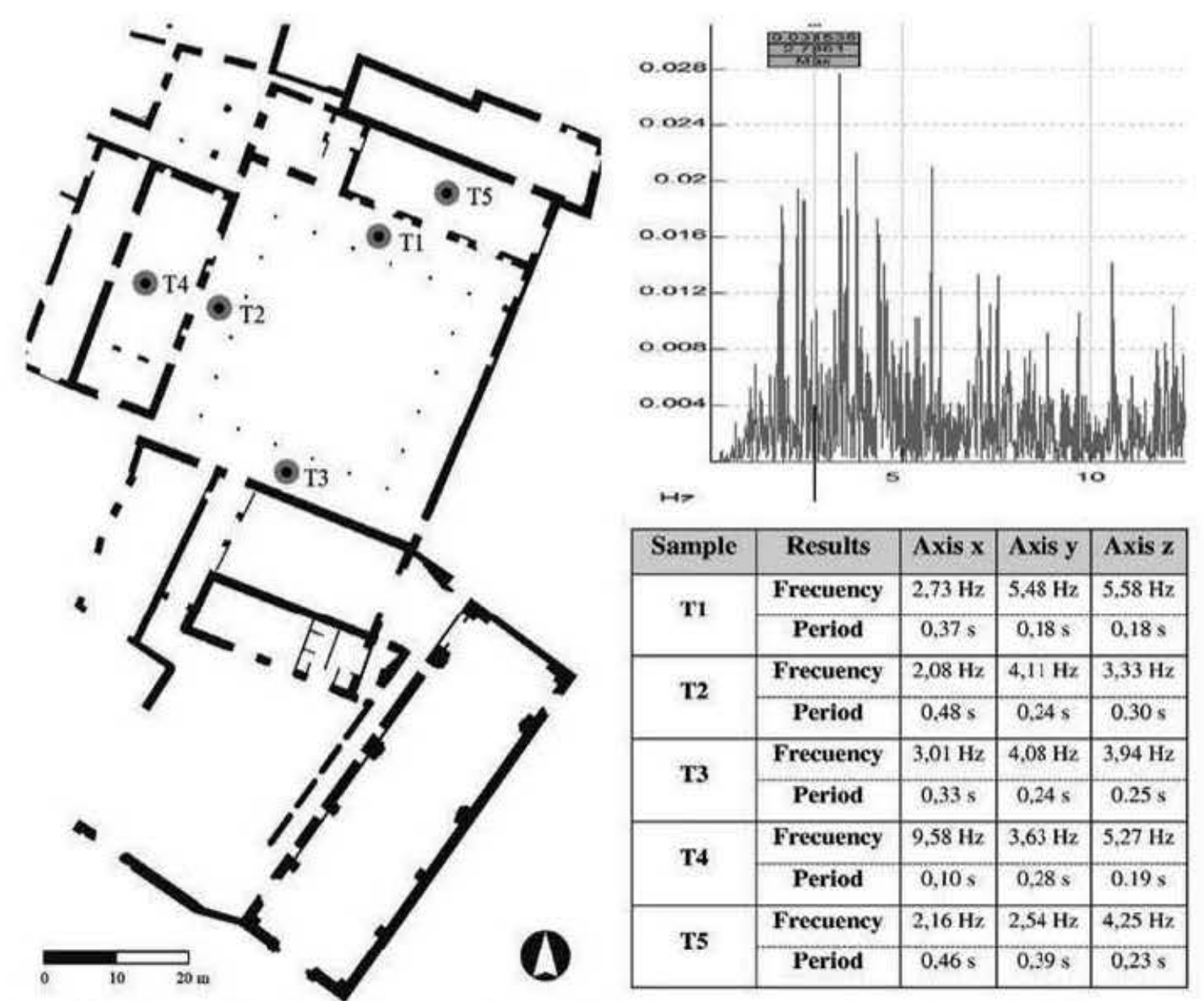

\begin{tabular}{|c|c|c|c|c|}
\hline Sample & Results & Axis x & Axis y & Axis z \\
\hline \multirow{2}{*}{ T1 } & Frecuency & $2,73 \mathrm{~Hz}$ & $5,48 \mathrm{~Hz}$ & $5,58 \mathrm{~Hz}$ \\
\cline { 2 - 5 } & Period & $0,37 \mathrm{~s}$ & $0,18 \mathrm{~s}$ & $0,18 \mathrm{~s}$ \\
\hline \multirow{2}{*}{ T2 } & Frecuency & $2,08 \mathrm{~Hz}$ & $4,11 \mathrm{~Hz}$ & $3,33 \mathrm{~Hz}$ \\
\cline { 2 - 5 } & Period & $0,48 \mathrm{~s}$ & $0,24 \mathrm{~s}$ & $0.30 \mathrm{~s}$ \\
\hline \multirow{2}{*}{ T3 } & Frecuency & $3,01 \mathrm{~Hz}$ & $4,08 \mathrm{~Hz}$ & $3,94 \mathrm{~Hz}$ \\
\cline { 2 - 5 } & Period & $0,33 \mathrm{~s}$ & $0,24 \mathrm{~s}$ & $0.25 \mathrm{~s}$ \\
\hline \multirow{2}{*}{ T4 } & Frecuency & $9,58 \mathrm{~Hz}$ & $3,63 \mathrm{~Hz}$ & $5,27 \mathrm{~Hz}$ \\
\cline { 2 - 5 } & Period & $0,10 \mathrm{~s}$ & $0,28 \mathrm{~s}$ & $0.19 \mathrm{~s}$ \\
\hline \multirow{2}{*}{ T5 } & Frecuency & $2,16 \mathrm{~Hz}$ & $2,54 \mathrm{~Hz}$ & $4,25 \mathrm{~Hz}$ \\
\cline { 2 - 5 } & Period & $0,46 \mathrm{~s}$ & $0,39 \mathrm{~s}$ & $0,23 \mathrm{~s}$ \\
\hline
\end{tabular}

Figure 2. On the left, natural vibrations site plan. On the right, graphic sample and results table.

Very high values in room 1 floor slab, since it is not from slab consolidation works, could be due to added constriction from injections performed in the subsoil from the adjacent building. 
$\mathrm{Z}$ axis values are quite similar because of wood slabs frequencies, normally over $4 \mathrm{~Hz}(0,25$ s).

High relative periods in the cloister longitudinal axis means lack of arcade tracing, whilst horizontal plane values in room 2 are below usual, meaning the lack of model rigidity.

\subsection{Soil test pits}

Soil test pits on the terrain are the most aggressive system of all the used, but is the only way to have accurate measurements from some elements like walls depth and thickness, support plane depth, etc. (Povedano, 2013).
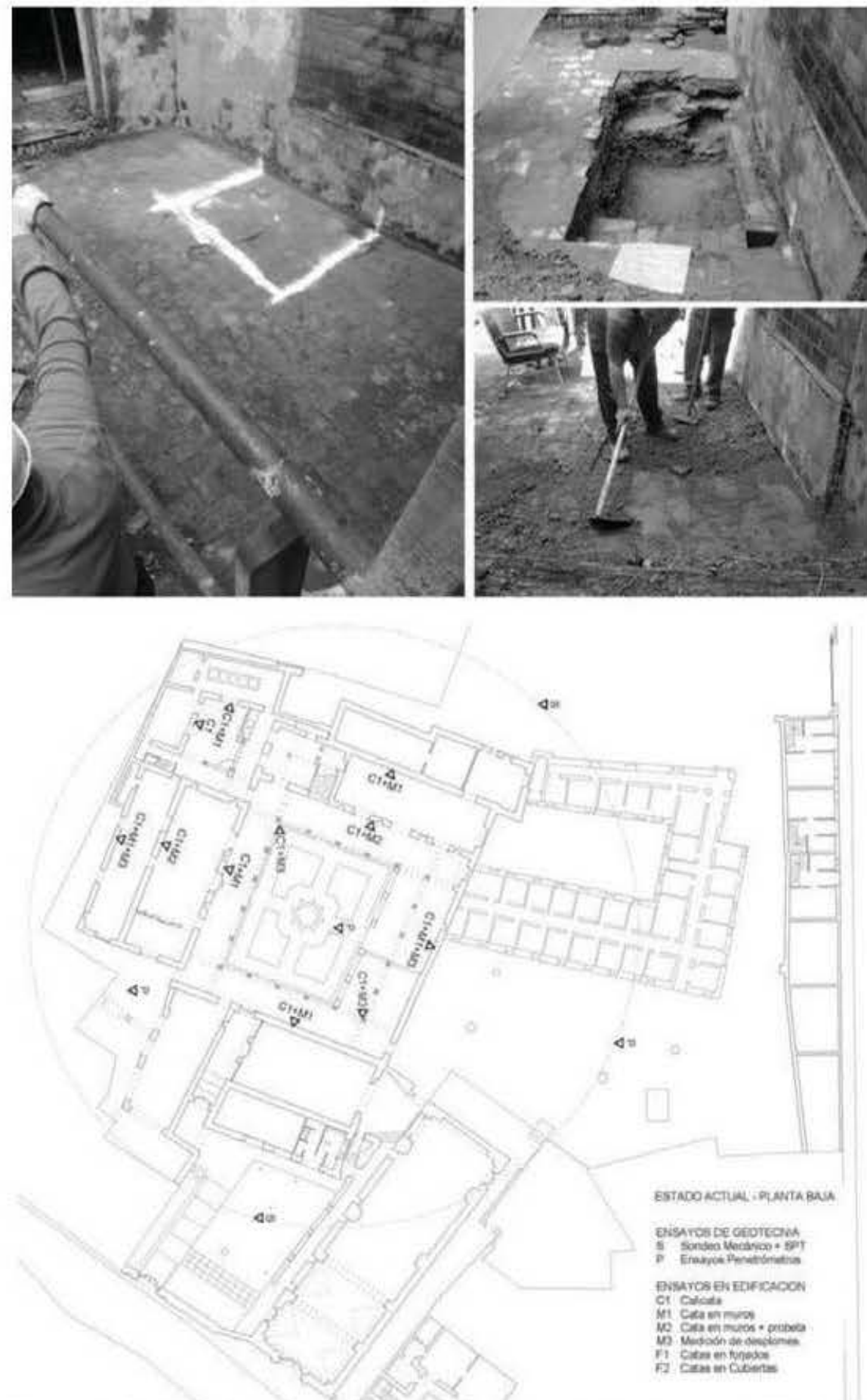

Figure 3. On top, test campaign photos showing soil pits placement. At the bottom, Nuestra Señora de los Reyes Convent site plan including test location. 


\section{LIQUEFACTION STUDY}

Liquefaction is crutial in the study of Heritage. In case of the city of Seville, the existence of large sand layers endangering the conservation of many historic buildings non designed to support this issue, being this the reason of the study with the following results (Jaramillo, 2013).

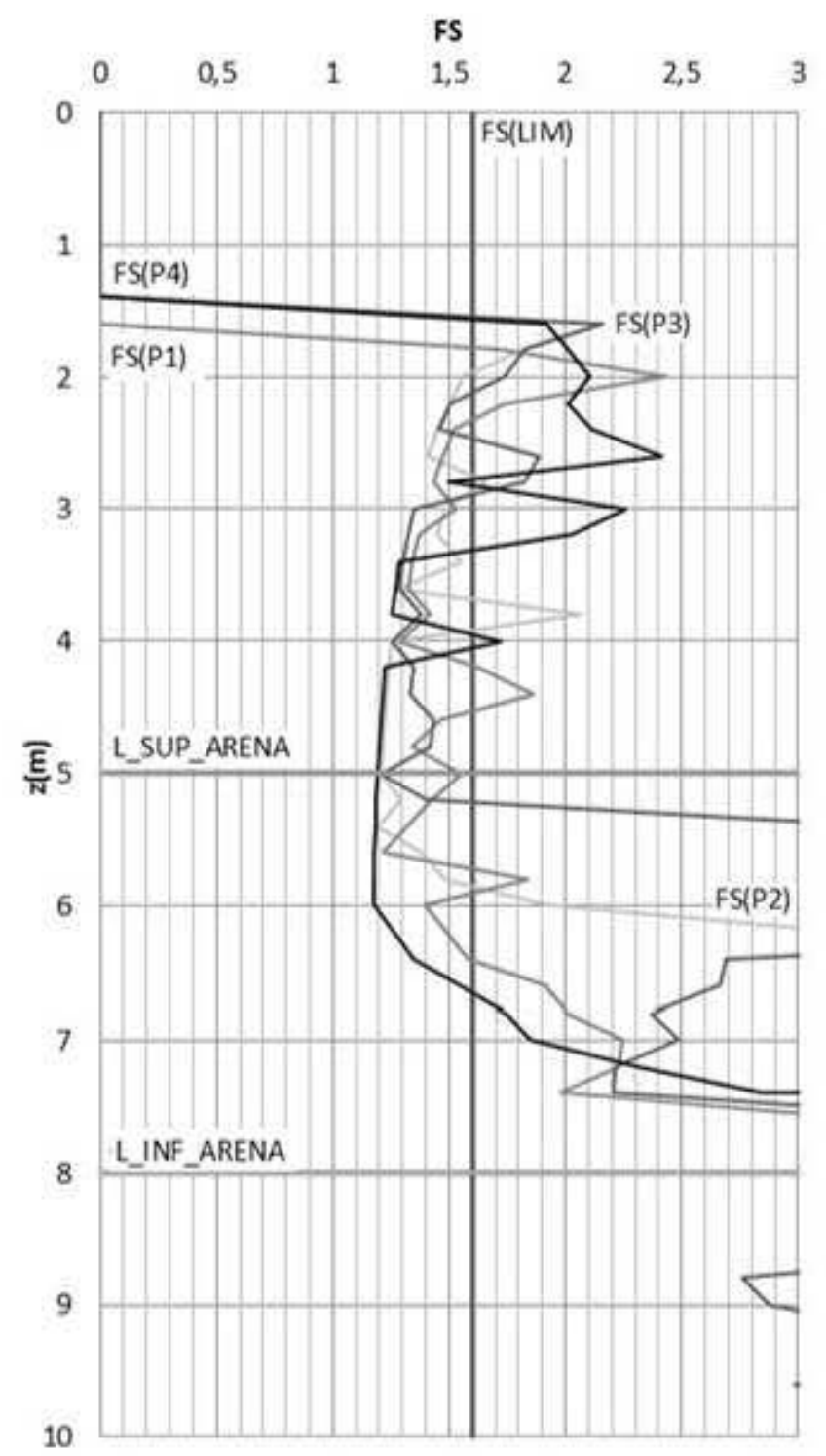

Figure 4. Safety ooefficient is below 1.5 until 6-6.6 meters depth, which is less than minimum required by Spanish Technioal Building Regulations (CTE) and NCS-2002 Seismic Regulation.

In general, this ground has a safety coefficient on to 1 but not reaching the 1.5 as minimum value that we consider needed for heritage buildings tipology.

This risk also leads us to propose ground improvement works in the first 8 meters.

\section{GEOTECHNICAL MAPS}

Geotechnical maps in Seville have been updated with seismic data including $\mathrm{C}$ terr ain coefficient, $\mathrm{S}$ coefficient and seismic acceleration both for special and normal relevance buildings. 
For the seismic characteristics study, we have a file with 350 recognition points, of which more than $60 \%$ reach 30 meters depth. Most of them have been provided by UTE Metro de Sevilla company, being the base to stablish line 1,2 and 3 excavations.

Same level curves for clay ceiling have been processed previously, sand-limestone, gravel and loams, phreatic level and filling surface thickness.

These curves have been obtained through Surfer, a calculation program that generates topographies from a database cloud points network.

In every borehole possible, by reaching 30 meters or a layer fairly homogeneous depth, we have obtained $\mathrm{C}$ terrain coefficient, $\mathrm{S}$ coefficient and seismic acceleration.

Main conclusion is a detailed seismic analysis is needed for buildings placed in particular points, since they may have an important acceleration value (ITE, 2013).

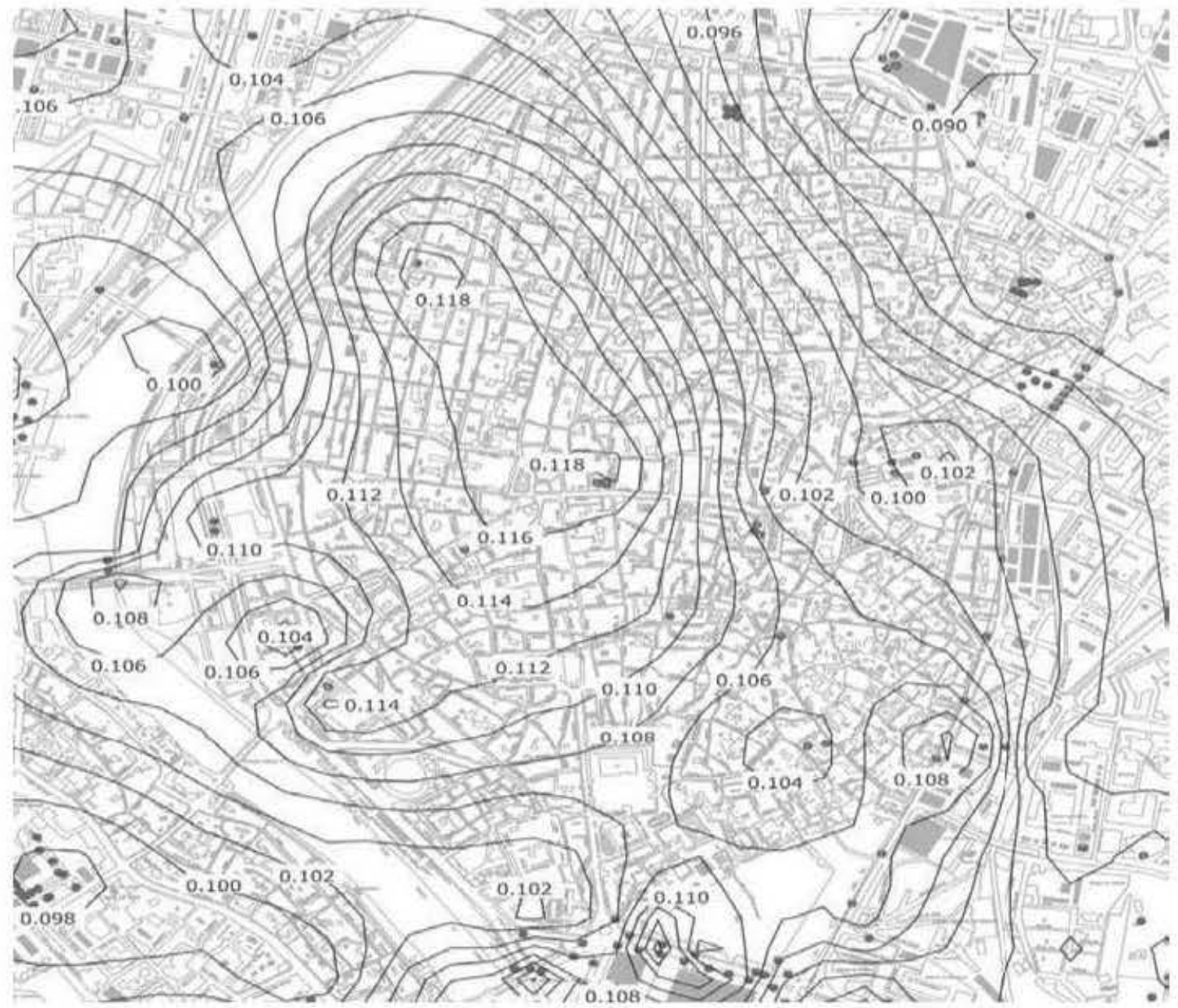

Figure 5. C terrain coefficients floor plan in Seville, coming from 1.1 to $1.7, \mathrm{~S}$ values going from 0.88 to 1.37 , and seismic acceleration between 0.06 to 0.1 .

\section{CONCLUSIONS}

From tests performed, profiles have provided the following charecteristics of the terrain.

Regarding to seismic features and according to NCSE-02 regulation, for Seville, acceleration coefficient is $0.06 \mathrm{~g}$ and $\mathrm{K}$ contribution coefficient is 1.1 .

New building use needs better security and structure conditions, so a terrain njections network is recommended to homogeneise the surface layers, both the very soft and the layer from adjacent constructions with cement residues and could be rigid points. 
C terrain coefficient on this plot is very high reaching 2 before terrain improvement, and could reach the value of 1.5 after it.

Destructive and non destructive testing are related on the checkpoints. The updated geotechnical mapping of Seville which allows to have seismic characteristics both from normal and special relevance city buildings (monuments and singular buildings) (Jaramillo, 2013).

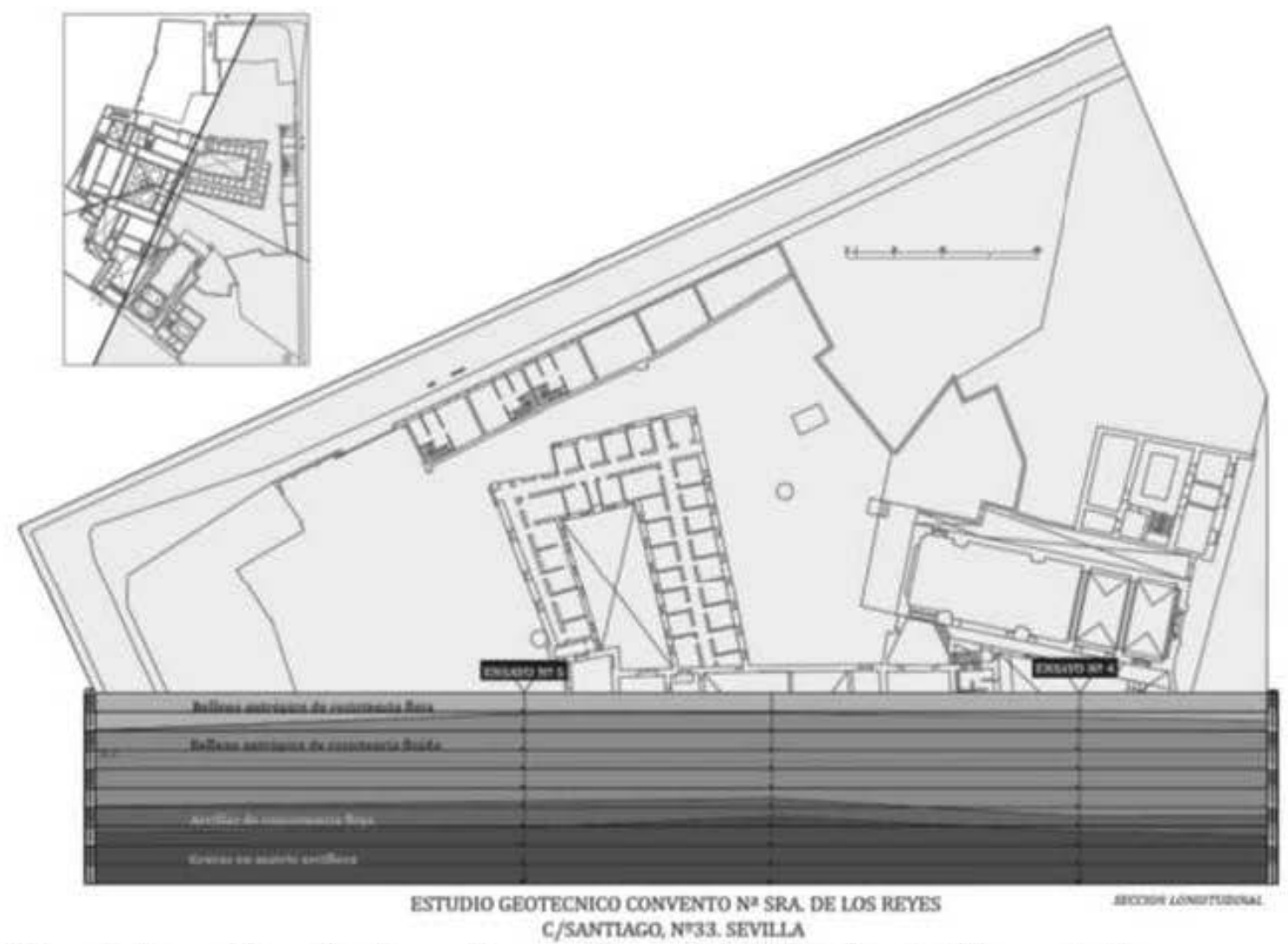

Figure 6. Convent floor plan shows relevance of ground study in heritage buildings protection.

\section{REFERENCES}

Código Técnico de la Edificación (CTE). 2013. Madrid: Ministerio de Fomento.

Iso 4866/1990-rev 94 y 96: Mechanical vibration and shock. Vibration of builtings. Guidelines for measurement and evaluation of their effects in buildings. Intemational Organization for Standarization. Geneve, Switzerland.

Jaramillo Morilla, A. 2013. Estutio Geotécnico parcela Antiguo Convento Nuestra Señora de los Reyes. Sevilla.

Jaramillo Morilla, A \& Huete Fuertes, R. \& Rodriguez Liñan, C. 2005. Protocolo de Inspección Técnica de Edificaciones ITE. Sevilla: Colegio Oficial de Arquitectos de Sevilla

Norma de Construcción Sismorresistente Española (NCSE-02). 2002. Madrid Ministerio de Obras Públicas y Transportes.

Povedano, J. E. 2013. Informe de resultados:. Ensayos del Laboratorio de Control de Calidad para el Convento de Virgen de los Reyes. Sevilla: Consejería de Formento y Vivienda. Junta de Andalucía (unpublished technical report). 